\title{
Mısır Baharı Sonrası Ülkenin Siyasî ve Politik Hareketliliğinin Kurgusal İzdüşümü: Bâbu'l-Hurûc ve İzzeddîn Şükrî Feşîr
}

\author{
Doç. Dr. Asiye Çelenlioğlu \\ Fatih Sultan Mehmet Vaklf Üniversitesi \\ Eğitim Fakültesi, Yabancı Diller Eğitimi Bölümü \\ acelenlioglu@fsm.edu.tr
}

Öz

1974 yılında Huntigton'un “Üçüncü Dalga” olarak adlandırdığı demokratikleşme süreci başladığından buyana Doğu Avrupa, Doğu Asya ve Afrika'da demokrasiye geçen ülke sayısındaki artışa rağmen, otoriter rejimle yönetilen Orta Doğu ülkelerinin bu dalgadan etkilenmemesi dikkat çekicidir. 2010 yılında Tunus'ta başlayan halk ayaklanması diğer Ortadoğu ülkelerine sıçradığında demokratikleşmeye dair beklentiler, bölge ülkelerinin kendi iç ve dış dinamiklerinden kaynaklanan nedenler sonucu boşa çıkmış, bu hareketlilik yerini devam eden kaos ortamına bırakmıştır. Sosyal zeminden beslenen yazarların bu heyecanı dile getiren eserleri Mısır başta olmak üzere diğer ülke edebiyatlarında yer alırken okuyucu, devrimin tarih sayfalarına yansıyan nesnel ifadeleri yerine bu eylemlerde yer alan tarafların duygusal arka planında yolculuk yapma fırsatı elde etmiştir. Bu çalışma Mısır'da 2011 yılında meydana gelen devrimden bir yıl sonra kaleme alınan ancak; tarihi, siyasi ve politik perspektifin o güne kadar yaşanmışlı̆̆ından hareketle ülkenin sekiz yıllık geleceğini kurgulayan Bâbu'l-Hurûc adlı romanı sosyolojik ve politik zeminde değerlendirmeyi hedeflemektedir.

Anahtar Kelimeler: Mısır, Devrim, Bahar, Edebiyat, İzzeddîn Şükrî Feşîr.

\section{Fictional Projection of the Political and the Political Movement of the Egypt After the Egyptian Spring: Bab el-Huruc and İzzedin Shukri Feshir}

\section{Abstract}

It is noteworthy that since the democratization process, which Huntigton called the "Third Wave" in 1974, began to increase, the number of countries that went to democracy in Eastern Europe, East Asia and Africa was not affected by this wave. When the popular uprising, which started in Tunisia in 2010, spread to other Middle Eastern countries, expectations regarding democratization have been in vain as a result of the local and foreign dynamics of the countries in the region, and this mobility has been replaced by an ongoing chaos environment. While the works of the authors who are fed from the social ground expressing this excitement take place in the literature of other countries, especially in Egypt, the reader had the opportunity to travel in the emotional background of the parties involved in these actions instead of the objective statements reflected in the history pages of the revolution. This study aims to criticize the novel Bab el-Huruc which was written a year after the revolution in Egypt in 2011 based on the historical and political perspective to date.

Keywords: Egypt, Revolution, Spring, Literature, İzzedin Shukri Feshir. 


\section{Gíriş}

Sosyal bilimlerin XX. yüzyılda sınırları birbirinden keskin çizgilerle ayrılan tarih, edebiyat, sosyoloji, uluslararası ilişkiler gibi alt disiplinleri XXI. Yüzyılda interdisipliner çalışma adı altında veri paylaşımına yönelmiş, söz konusu birliktelik edebiyat sosyolojisi gibi bazı alanlarda meşru zemine oturmuştur. Platon, taklitten ibaret olduğu düşüncesiyle sanatı değersizleştirirken bile maddi dünyadan beslendiği gerçeğini kabul etmiş, Aristo, ise bunun saf taklit olmayıp, sanatçının iç görüsüyle harmanlanmış bir yorum olduğu tezini savunmuştur. Sanatın sanat için mi toplum için mi olduğu sorusu farklı dönemlerde farklı şekilde cevaplana dursun sanatçının içine doğduğu maddi alemi yorumlayarak yansıttığı gerçeği değişmemiştir.

Edebiyat toplumla bağını, hem yazarın içinde doğduğu hem de yazarın yansıttığı yapı olarak kuvvetlendirirken genelde edebi eserleri özelde romanı, ait olduğu toplumun siyasi ve sosyal şartlarından bağımsız olarak anlamak mümkün olmayacaktır. Bazen bir eseri dış dünyaya dönük olarak, sosyolojik, Marksist ve tarihsel zeminde anlamaya çalışmak da yetmeyip yazarın hayatından esere yansıyan yanları bulup çıkarmak, onu bütün yönleriyle değerlendirmek gerekir.

Bu anlamda, İzeddîn Şükrî Feşîr'inn ${ }^{1}$ Mısır Baharı' nın gerçekleştiği 2011 yılından bir yıl sonra, ülkenin tarihi geçmişi ve mevcut şartlarından hareketle, 2020 yılına kadar sosyal ve siyasî arenada yaşanabilecek politik ve ekonomik olayları kurguladığı romanı Bâbu'ul Hurûc'u, edebiyatı besleyen diğer disiplinlerden yardım alarak yorumlamak mümkün olacaktır. Yazar; romanda ihtisas alanı olan politikayı ülkenin siyasî geçmişinden gelen aktörler, halkın beklentileri, uluslararası siyasetin iç politikaya yansıması gibi çoklu denklemlerin olasılığında nakış gibi işlemiş daha da ilginci ülkenin gerçek siyasetiyle büyük ölçüde örtüşen bir senaryo kurgulamıştır.

Mısır edebiyatında devrim sonrası yazılan pek çok roman tarih sayfalarına yansıyan rakamsal ifadeler yerine, devrimin taraflarını oluşturun iktidar, asker, devrime katılan ya da uzak duran, Müslüman ya da Kıpti bütün halkı simgeleyen karakterlerle duygusal arka planı okuyucuya yansıtmada oldukça başarılı olmuştur. Söz konusu romanın, diğerlerinden farklı devrimin hemen akabinde yazılmasına rağmen sonraki sekiz yılı gerçeğe yakın kurgulaması, politik aktörleri belirleyip denklemler oluştururken ihtisas alanı olan politikayı çok iyi kullanmasıdır.

\footnotetext{
1 İzzedîn Feşîr babasının görevi nedeniyle 1966 yılında Kuveyt'te doğmuştur. 1987 yılında Kahire Üniversitesi Siyaset Bilimi Bölümünden mezun olmuş, yüksek lisansını Ottawa Üniversitesi Uluslararası İlişkiler (1995), doktorasını Montreal Üniversitesi Siyaset Bilimi (1998) alanında tamamlamıştır. 2007 yılına kadar aralıklarla diplomat olarak çalışmış daha sonra Kahire'de Amerikan Üniversitesi Siyaset Bilimi'nde ders vermeye başlamıştır. 2011 yılında Tahrir Meydanı'ndaki devrimci harekâta katılmış bu tarihten sonra Mısır Demokratik Siyasî gruplarına ve Cumhurbaşkanı adaylarına danışmanlık yapmıştır. Dinî otoriter kurallar oluşturmak için demokratik yöntemleri kullandıkları iddiasıyla Müslüman Kardeşler iktidarına son verilmesini desteklemiş, geçiş döneminde demokratik dönüşümün gerçekleşmesini ummuştur. Kısa ömürlü bir hükümet komitesinin bağımsız üyesi olmayı kabul etmiş (2013) ancak söz konusu hükümet ifade özgürlüğünü kısıtlayan bir yasa çıkardığında açıkça kınamıştır. Yazılarında otoriterliği kınamaya devam eden Feşîr 2014 yılında General Abdu'l-Fettah el-Sîsî̀nin başkan seçilmesinden sonra kamusal alandan çekilmiştir. Washington Post ve Mısır'ın tanınmış gazeteleri eş-Şurûk ve et-Tahrîr' de siyasi yazıları yayınlanmaktadır. Yazarın diğer romanları aşağıdaki gibidir: Maktelu Fareddîn (Fahreddin'in Öldürülmesi, 1995), Esfâru'l- Ferâîn (Firavun Yolculuklarl, 1999), Gurfetu'l-inâyeti'l- Mürekkeze (Yoğun Bakım Ünitesi, 2008), Ebû Amr el-Misrî (Mısırlı Ebû Amr, 2010), İnâgu İnde Cisri Brûklîn (Brooklyn Köprüsünde Kucaklaşma, 2011), Bâbu'l-Hurûc (Çıkış Kapısı, 2012) , Kullu Haza'l-Hera' (Bütün Bu Saçmalıklar, 2017)
} 
Ortadoğu ülkelerinde demokrasi açmazının nedenleri siyasi arenada konuşula dursun yazar, demokrasinin paydaşlarını oluşturan karakterlerle kurguladığı romanda bu konuya yönelik öz eleştiride bulunur. Asker ve polis teşkilatı, halk ve bürokratların nasibini aldığ1 bu eleştirirler demokrasi önündeki engellerin ülke içinde nasıl yorumlandığıyla ilgili bilgi vermektedir.

\section{Misir'da demokrasi sorunu}

1974 yılında Huntigton'un “Üçüncü Dalga” olarak adlandırdığı demokratikleşme sürecine rağmen Ortadoğu ülkelerinde totaliter rejimlerin direncine yönelik yorumlar kültürel, yapısal ve kuramsal içerik taşımaktadır. İslam dinine mensup Arap toplumunda demokrasinin dinin öğretileriyle uyuşmadığı iddiası üzerine inşa edilen kültürel analizlerin kökeni batıda yapılan müsteşrik çalışmalara dayanmaktadır. 1990 yılından itibaren bu iddiayı çürüten antitezler alan araştırmacıları tarafından yapıla gelmektedir (Esposito ve Voll, 2012). Yapısal yaklaşım Arap rejimlerinin sürekliğini ekonomik boyutta değerlendirirken yeraltı zengin $\neg$ liklerinden elde edilen gelirlerle şekillenen "rantiye devlet" ekonomisini buna neden olarak göstermektedir (Demirtaş, 2017, s. 56). Kuramsal yaklaşım ise Arap rejimlerinin sürekliliğini iktidarı paylaşan güçlerin etkileşimine bağlamaktadır (Bekaroğlu ve Kurt, 2015, s. 7-19).

Ortadoğu ülkelerinde demokrasi açmazıyla ilgili tek bir senaryo oluşturmak mümkün olmayacaktır. Bölgenin yapısal ve kuramsal kimi zamanda kültürel şartlarından kaynaklanan formasyonun denklemi her ülkede farkı olduğu için ülkelerin demokrasi mücadeleleri de farklı seyretmektedir.

$\mathrm{Bu}$ ülkeler içinde Mısır söz konusu olduğunda rejimin koalisyon döneminde paydaşlarla, tek başına iktidar olduğu dönemlerde muhalefet partileriyle kurduğu ilişki ve askerin devlet içindeki yapılanmadan aldığı pay bu denklemin taraflarını oluşturmaktadır. Sivil toplum örgütlerinin muhalif tavırlarının yönetilmesi de buna dâhildir. İktidar dışında kalan muhalif partilerin etkin siyaseti baskı ve tutuklamalarla sekteye uğrarken İslami örgütlere atfedilen "Radikal İslam" söylemi önlerinin kesilmesi için meşru bir zemin oluşturmuştur. Bu kombinasyona diş güçlerin rejim desteğini de ilave etmeyi unutmamak gerekir. Mısır'da ABD'nin Büyük Ortadoğu Projesi çerçevesinde başlattığı demokratikleşme söyleminin (Bekaroğlu ve Kurt, 2015, s. 19) etkisi altında yargının kolektif çabası ile sıkı gözetim altın da yapılan 2005 seçimlerinde meclise rekor sayıda muhalif millet-vekili girebilmiştir (Bekaroğlu ve Kurt, 2015, s. 19).

Koalisyon hükümetlerinde uzlaşmanın mümkün olmadığı dönemlerde taraflardan birinin istifası hükümetin düşmesine neden olurken 1981 yılında Mübarek'in devraldığ iktidarda seçimlerin demokratik şartlarda yapılmaması iktidarın mecliste en fazla sandalye sayısına sahip olmasıyla sonuçlanmıştır. Muhalefetin adil olmayan seçim atmosferine gösterdiği tavır boykottan tam katılıma kadar farklılık gösterirken 1987 seçimlerine tam ittifakla giren muhalif partiler mecliste elde ettikleri 60 sandalye sayısıyla halkın isteklerini görünür kılmışlardır. Ancak Mısır siyasetinde 1952 Hür Subaylar Darbesi ile başlayan askerin etkin rolü Mübarek'in otoritesini paylaşmadan yoluna devam etmesine fırsat vermiştir.

Mısır'da demokratik rejime geçmenin önündeki engel Orta doğu devletlerinde otoriter rejimlerin devamını açıklayan yapısal yaklaşımdan ziyade halkın tepesinde iktidarın ise arkasında konuşlanmış askeri gücün varlığıdır. Demokratik hareketin Tunus'ta Mısır'a 
nazaran daha başarılı olmasının altında yatan neden de ordunun rejim içindeki gücünün Misır'a nazaran daha az oluşudur.

Askerin rejim içindeki etkin rolü darbeyle iktidara geldiği 1952 yılına dayanmakla birlikte, Nasır'dan sonra İftitah programıla liberal ekonomiye geçiş yapan Sedat döneminde ticari imtiyazlar elde eden askerin Mübarek döneminde de artmaya devam eden ekonomik gücü, Arap rejimlerine prim kazandıran Filistin sorununun daima aktif oluşu, iktidarın paydaşlarından biri olsa da siyasi mekanizmalar karşısında kurumsal bir özerkliğe sahip olmasını sağlamıştır (Bekaroğlu ve Kurt, 2015, s. 24).

Kahire'de Siyasal Bilimler okuduktan sonra Kanada'da aynı alanda doktora eğitimi alan İzeddîn Şükrî́nin söz konusu romanda ülke siyasetinde etkin aktörlerden oluşan karakter kadrosuyla devrim sonrası kurguladığı politik denklemi anlamlandırmak için genelde Ortadoğu özelde Misır rejimiyle ilgili verilen yukarıdaki malumata son olarak siyasal fırsat alanları yaklaşımını da eklemek gerekecektir.

Mısır'da geniş yelpazede birbirinden farklı görüşe sahip siyasi birimlerin koalisyon hükümetlerinde bir araya gelişini açıklayacak fırsat alanları yaklaşımı romanda oluşturulan siyasi kombinasyonlara farkındalık kazandıracaktır. Bu analizin temel iddiası rejimin muhalefete açtığı alanları değerlendirmesidir. Bu etkileşim zaman içerisinde ideolojilere açılım kazandıracağı gibi söz konusu fırsatları kullanmaktan ibaret de kalabilir. İhvan'ın koalisyon hükümetlerinde ya da muhalefette rejimle kurduğu pragmatik ilişkileri bu çerçevede yorumlamak gerekir (Bekaroğlu, 2017, s. 111-163).

\section{Bâbu'l-Huruc romanı}

İzzeddîn Şükrî Feşîr'in 2012 yılında okuyucuyla buluşan Babu'l-Hurûc (Çıkış Kapısı) adlı romanı Hüsnü Mübarek döneminde başkanlık sarayında tercüman olarak görev yapan Ali Şükrî adlı gencin Oğlu Yahya' ya yazdığı 15 bölümden oluşan 473 sayfalık bir mektuptur. Yazarın Fasih Arapça ile edebi üslupta kaleme aldığı roman Ali Şükrî'nin otobiyografisi mahiyetindedir. 1991 yılında başkanlık sarayında mütercim olarak göreve başlayan Ali Şükrî daha sonra başkanın özel tercümanı olarak devlet başkanlarıyla yaptığı toplantılara iştirak etmiş 2011 direniş hareketiyle başlayan siyasi akışı 2020 yılına kadar kendi hayat hikâyesiyle harmanlayarak oğluna anlatmıştır. 2012 yılında kaleme alınan romanın başarısı yazarın ülke siyasetiyle ilgili ön gördügü tahminlerin büyük oranda gerçekle örtüşmesidir (Feşîr, 2013, s. 15).

Pekin'de askeri ateşe olarak görev yapan babası sebebiyle Kahire'de başladığı Felsefe eğitimine sadece sınavlara girmek suretiyle devam eden Ali Şükrî, bulunduğu ülkede misafir öğrenci olarak felsefe derslerini takip etmektedir. Eğitimi sırasında bu ülkede tanıştığı kız arkadaşıyla ilişkisi babası görevini tamamlayıp ülkeye dönmek zorunda kaldığında biter. Her ne kadar Ali Şükrî, Pekin'de kalarak eğitimine devam etmek istese de babası sarayda mütercim olarak çalışmasına karar vermiştir. Erkek kardeşi Ömer eğitimine İtalya' da devam etmek istediğinde pasif direnişine karşı koyamayan babası izin verirken Ali Şükrî'nin munis tabiatı iş ve özel hayatını da şekillendiren bir unsur olur.

Romanda siyasi bir karakter olarak karşımıza çıkacak olan İzzeddîn Fehmî ile anlatıcı yazarın arkadaşlı̆̆ı çocukluk yıllarına dayanır. Yazar romanda Fehmi karakterini oluştururken ilk satırlardan itibaren onu ülke siyasetinde oynayacağı role hazırlar. 
Gündüzleri okulda, akşamları evde otururken ya da Nil kenarında vakit geçirirken, hayata hep birlikte atıldık. Birbirimize kalbimizi açmış, ikiz kardeş gibi olmuştuk. Ali Şükrî ve İzeddîn Fikrî. Fikrî benim gibi sakin ve hayalperestti. Biz yaştaki ergenlerin ilgi duyduğu şeylerden daha fazla, ideolojiler, kitaplar ve dünyanın durumuyla ilgilenirdi. Fakat o benden daha atılgan, büyüklere, özellikle öğretmenlere karşı çıkıp cevap vermede ve kendini savunmada benden daha becerikliydi. Bu yüzden rolleri bölüşmüştük. Ben yemek, annemin özenli ilgisi, ortadan kaybolan babamın kitapları gibi imkanları akşamları evde să̆lıyor İzzeddîn öğretmenlerle ya da geç kaldığımı ve ortadan kaybolduğumuz zamanlarda annemle tartışıp bizi savunma görevini üstleniyordu. (Feşîr, 2013, s. 24).

İzzeddîn Kahire üniversitesinde iktisat ve siyasi bilimler okur. Daha sonra Kanada'ya giderek lisans ve doktora eğitimini tamamlar. Askeri İstihbarat Şubesinde göreve başlayan anlatıcı yazar ise askerlik görevini tamamladıktan sonra Bakanlıkta mütercim olarak çalışmaya başlamıştır. İki arkadaşın yolları darbeden sonra siyasi arenada kesişecektir.

Anlatıcı-yazar körfez savaşı boyunca vaktini yabancı gazetelerde yayınlanan makaleleri tercüme etmekle geçirir. Göreve başladıktan bir yıl sonra Devlet Başkanı'nın yabancı unsurlarla yapacağı birkaç toplantıya çevirmen olarak katılmıştır. Başlangıçta yaptığı işin ehemmiyetini sorgularken başkana yakın olmanın verdiği ayrıcalık, zamanla bunu unutturur.

Bu durum yıl boyunca beş- altı kez tekrar etti. Bu süre zarfinda başkan ne benimle konuştu, ne de varliğımı fark etti fakat, birkaç kez onunla aynı yerde bulunmak karşı koyamadiğın bir kuvvet ve önem duygusu veriyor. Çünkü sıradan biriyken, sürekli başkanı görebilen çok az sayıdaki insanın arasında buluyorsun kendini. Aralarında olmak istesen de istemesen de sana ayrıcalık kazandırıyor. Yavaş yavaş bu ayrıcalı̆̆a alışıyor, kendini, kuvvetini keşfediyor ve bu insanlarla ve tabii başkanla birlikte olmaya devam etmek istiyorsun. (Feşîr, 2013, s. 51).

Yazar, anlatıcı-yazarın başbakanlık tercüme ofisinde çalışırken tanıştığı Sâlı Kasapçı ve Mahmûd Beşîr arasındaki ilişkiyi hikâye ederek onları okuyucuya tanttırken ileride kurgulayacağı politik manevralara zemin hazırlamaktadır.

Gazetelerden birinin başbakanlık temsilcisi olan Salî zeki ve son derece çekici bir kadındı fakat onu farklı kılan içeride ve dışarıda hükümet birimleriyle olan geniş ilişkisiydi. Bu ilişki onu seyyar hizmet merkezi haline getirmişti. Bir akrabanm işe girmesinden bina ruhsatına kadar yapılacak işi olan herkes ona müracaat ederdi. Salî sihirli gücünü kimseden esirgemez tanısın tanımasın ona sığınan herkese yardım elini uzatırdı. (Feşîr, 2013, s. 54).

Mahmût Beşîr birlikte olduğu Salî́nin başbakanlıkta yüksek rütbeli bir çalışanla daha ilişkisi olduğu öğrenince öfkelenerek söz konusu şahsı döver. Beşîr ve Salî görevden alınır. Anlatıc1- yazar kendisine zarar vereceğinden endişelenerek arkadaşıyla irtibata geçmek istemez. Mahmût'un iyi olduğuna dair haber ulaştırdığı telefon memuru İfâf, kardeşleri Mirfet ve Hasan romanın kurgusunda yerini alır.

Anlatıcı-yazar babasının Askeri muhafız birliğinde görev yapan arkadaşı Albay Kattân aracılığıyla Başbakanın simultane tercümanı olarak terfi etmiştir. Babasının ölümünden sonra 1999 yılında annesinin isteği üzerine Kattân'ın kızı Nidâ ile evlenir (Feşîr, 2013, s. 78). Daima kırılgan bir camın aralarında perde olduğu bu evlilik (Feşîr, 2013, s. 80) kısa süre sonra sadece kâğıt üzerinde kalacaktır. 
Romanda devletin işleyişi ve uluslararası toplantıların basına yansıyan yüzünün ardında nelerin yaşandığıyla ilgili anlatıcı yazarın sözleri, belli bir iktidardan ziyade genel olarak sisteme yöneliktir. Onun başlangıçtaki eleştirel tutumu zamanla öğrenilmiş çaresizliğe dönüşecektir:

Başlangıçta, içeriği boş bir toplantıyı başkana vakit kaybettiren üzücü bir olay olarak görüyordum. Birbirine benzeyen birkaç toplantıdan sonra, bizi önemsiz olanlara götürdüklerini zannettim. Yine öyle bir toplantı sonrası samimiyetimi ilerlettiğim Başbakanın basın sözcüsüne "ziyaretçiler başkanın vaktini boşa harcadılar" deyiverdim. Beni kınayarak "Toplantı çok iyi ve verimli geçti." cevabını verdi. O zaman çok şaşırmıştım fakat üzerinden aylar sonra yıllar geçince bu toplantıların büyük bir kısmının saçmalık olduğunu anladım. Fotoğraf çekip kanallarda yayınlamak, tartışmaları halka duyurmak ve onlara tartışılan konuların çok önemli olduğu hissini vermekten başka bir amact yoktu. Sonra ne yapılan bu toplantıda ne de yapılması planlanan toplantıda bir neticeye varılmaksızın yeni bir ziyaret ve toplantı kararı... Çaba sarf edildiği, plan ve projelerin uygulandığı hissi vermek dışında kayda değer bir şey olmadan şansa göre iyi ya da kötü şeylerin yaşandı̆̆g bir toplantıdan diğerine bir konferanstan ötekine... (Feşîr, 2013, s. 61-62).

Fıtratı gereği bütün bunları kabullenerek eviyle işi arasında günlük rutine alışan anlatıcı-yazarın doktora eğitimini tamamlayarak Kanada'dan dönen arkadaşı İzzeddînle, Mısır'daki sosyal ve siyasî hayat üzerine konuşmaları da öğrenilmiş çaresizliğini değiştirmez.

İzeddîn yıllarca ne fakültelerde ne de başka bir yerde iş bulamadı. Katıldı̆̆ı seminerlerde Misır üniversitelerinin köklü bir iyileştirmeye ihtiyacı olup bu hailiyle bir enkazdan ibaret oldukların söylemeye başladı. Bu sözleri, kendilerine ve bütün Mısır halkına ihanet olarak kabul eden bazı Mısır üniversitesi öğretim üyeleri ona karşı çıktı. İzeddîn üniversiteler arasında yayılan bu sözleriyle tanındı ancak bu tanınmışlık da eleştirdiğ i enkazlardan birinde görev almasına yardımcı olmadı. Gerçekte işe alınmamasının tek sebebi bu da değildi. Üniversitelerin atama tüzüğ̈̈ istisnai durumlar dışında dışarıdan birine izin vermiyordu. Aynı zamanda iyimser arkadaşım sonunda yüksek başarı ve referansla elde ettiğ i diplomasının Mısır'da geçerli olmadı̆̆ııı keşfetmişti. (Feşîr, 2013, s. 74).

Başbakanın her toplantısına çevirmen olarak katılan, üstelik arşivi düzenlemek için her belgeyi gözden geçirmek zorunda kalan anlatıcı yazar, öğrendikçe suskunlaşır. Amerikan üniversitesinde öğretim üyesi olarak göreve başlayan İzzeddîn'le yaptıkları siyasî sohbetlerdeki susukunluğunu "Olayların arkasında yatan nedenleri öğrendikçe onları yorumlama gücümü yitirdim” (Feşîr, 2013, s. 82-83) diye açıklar. Mısır’ın geleceği için endişelenen İzzedîn Başbakanın kulağının dibinde oturup da onu uyarma cesareti göstermediği için arkadaşını eleştirmektedir.

Ben iyimserliğine tebessüm ediyorum. Alışılmışın dışında bir şey söylesem, başkan ya da başkası, beni hiç kimsenin duymayacă̆ını bilmiyor. Ne akademisyen İzzeddîn ne de anarşist Mahmûd, başkanlık sarayında daha önceden kararlaştırılıp söylenegelen, sınırlı sayıda kelimeyle sınırlı sayıda düşünce ve kalıp barındıran özel bir dil kullanıldı̆̆ını bilmiyor. Başka bir kelime, fikir ya da kalıp kullanacak olsan seni duymayacak ve anlamayacaklar. Tuşları çalışmayan bir bilgisayar gibi sana boş boş bakacak, bir süre sonra ya bir şey söylememişsin ya da söylediğin şaka yahut tuhaf bir fikirmiş gibi 
davranarak işlerine devam edecekler. Bu dili kullanmaya devam edersen seni ya gerçeklerimizi ve şartlarımızı anlamayan dĭgerleri sınıfına, ya da yabancı dil konuşan zengin sinıfina sokacaklar. (Feşîr, 2013, s. 89-90).

\section{Romanda siyasi ve politik manevralar}

\subsection{Misır Arap Baharı}

Hüsnü Mübarek'in iktidarda olduğu bu yıllar Ortadoğu'da otoriter rejimlere karş1 direniş hareketinin başladığı yıllardır. 2010 yılında Tunus'ta başlayan hareket 25 Ocak 2011 yılında Tahrir meydanına sıçradığında devrimcilerin hem fikir olduğu tek konu, daha fazla demokrasidir. Bundan sonraki süreçte farklı siyasi görüşteki direnişçilerin iktidarı ele geçirme konusundaki ihtilafı ülkeyi bir maceraya sürükleyecektir (Feşîr, 2013, s. 112). Yazar'ın 2012 yılında kaleme aldığı roman eylemlerin başladığ geçen süreçte tarafların bazen samimi bazen menfaat için yaptığı manevralar üzerine kurgulanmıştır.

Mısır devriminden sonra yazılan romanlarda tarihi akış yazarın siyasi temayülüne göre farklı şekillerde yorumlanmıştır. Tahrir meydanında toplanan halkla ilgili söz konusu romanın yorumu İhvân'ın organize ettiği harekete geniş halk cephesinden katılımın olduğudur. Devrime katılan siyasi oluşumların ihvandan çekinerek demokratik talepleri üzerine rejimle anlaşmaktan çekindiği de yazarın yorumları arasındadır (Feşîr, 2013, s. 109). Roman Alâ el-Asvânî'nn devrimin anatomisini anlattığı Cumhûriyye Keenne (Sahte Cumhuriyet) romanıyla kıyaslandığında İhvan'a karşı tutumu farklılık göstermektedir. Söz konusu roman ihvanın bireysel katılım dışında bir flama altında gösterilere katılmadığı ve askerle anlaşarak seçimlerde oyların büyük çoğunluğunu aldığı tezini savunmaktadır. Gerçek şu ki bu konuda yapılan çalışmalar İhvan'ın devrime bir flama altında toplanmadan bireysel katıldığını göstermiştir (Güvenilir, 2016, s. 140).

Göstericilere güç kullanmak istemeyen asker içinde muhalif bir grup, 'Baltacı' denilen eşkıyaların deve ve atlarla meydandaki direnişçilere saldırmasını planlar ancak İhvan ve Ultralar onlara birlikte karşı koyar (Feşîr, 2013, s. 110-111). Romanda devrim günlügünde yer alan Muhammed Mahmûd ${ }^{2}$ ve olaylarıyla Maspero ${ }^{3}$ olaylarına da değinilmiştir (Feşîr, 2013, s. 120).

\section{2. İlk seçimler ve İhvan'ın iktidarı}

Mübarek'in istifasından sonra geçiş hükümeti olarak idarî sorumluluğu üstlenen asker, yapılacak seçimlerde -daha sonra görüleceği gibi- İhvan'ın yüksek oy alacağ1 beklentisinde değildir, tam tersi, seçimlerin ülkenin mozaiğini yansıtacak şekilde sonuçlanacağını düşünmüştür (Feşîr, 2013, s. 117).

\footnotetext{
${ }^{2}$ Mısır'da, 19 Kasım 2011'de devrik lider Hüsnü Mübarek'ten sonra yönetimi elinde bulunduran askeri konseyin yetkilerini sivil yönetime bırakması için başlatılan gösteriler sırasında Muhammed Mahmud Caddesi'nde yaşanan olaylar.

2 Misır'da, 19 Kasım 2011'de devrik lider Hüsnü Mübarek'ten sonra yönetimi elinde bulunduran askeri konseyin yetkilerini sivil yönetime bırakması için başlatılan gösteriler sırasında Muhammed Mahmud Caddesi'nde yaşanan olaylar.

39 Ekim 2011'de, ülkenin güneyindeki Marinab Kilisesi'nin yıkılmasını protesto eden göstericilerle güvenlik güçleri arasında çıan çatışmalarda çoğunluğu Hristiyan, 27 kişinin hayatını kaybettiği gösteriler, "Maspero Olayları" olarak bilinmektedir.
}

SEFAD, 2020; (44): 15-36 
Seçim sonuçları açıklandığında askerin müdahalesini meşrulaştıracak İhvan karşıtı tutumun sadece askeri cephede değil halk arasında da yaşandığı tezini savunan anlatıcıyazar bunu aşağıdaki cümlelerle ifade eder:

Daha önce siyasetle ilgilenmeyen Safiye devrimle birlikte siyasi hayatın sıkı bir takipçisi olmuştu. Tahrir Meydanı'ndaki gösterilere kendisi katıldığı gibi üç oğlunu da katılması için teşvik ederken, bu konuda gevşek davranan büyük oğlunu ayıplamakla kalmıyor, kendi seçim bölgesiyle arkadaşlarının seçim bölgesindeki adayların ismini araştırarak onlar hakkında bilgi topluyor, arkadaş ve akrabalarna belirlediği en uygun ismi açıklıyordu. Evine yakın mescitte Kur'an dersleri tertip eden Safiye, İhvan ve Selefiler'den korkuyor, bazllarının farklı bir din görüşü benimsediğini diğerlerinin ise dini dünyevî amaçlarına alet ettiğini düşünüyordu. Seçim sonuçları açıklandığında coşkusu azaldı, siyasî gelişmeleri takip etmeyi ve tahrir Meydanı'na gitmeyi bıraktı.

Bir yandan annen Nida'da seyahatten ve Mısır dışına yerleşmekten söz etmeye başlamıştı. Başlangıçta şaka yaptı̆̆ııı sandım fakat şaka, tekrarlanıp detaylanmaya başladı. Tedirgindi. Ona göre Mısır bir avuç aşırılık yanlısı ve ucubeye teslim ediliyordu ve o, bu çılgınlı̆̆ın ortasında bir yaşam istemiyordu. Ne yapıp yapmaması gerektiğini söyleyen hocalar, yolunu kesen, ona ayıplayarak bakan adamlar istiyordu. Bana havada oksijenin azaldığın hissettiğini söylüyordu. Ne bu boğucu ortamda yaşamak, ne de akşamları medyada saçma ve rahatsız edici sözler duymak istemiyordu. (Feşîr, 2013, s. 121-122).

Romanda, askerin seçim sonuçları nedeniyle yaşadığı tedirginlikle (Feşîr, 2013, s. 122), siyasi oluşumların seçim sonuçlarını askerle İhvan arasında yapılan anlaşma (Feşîr, 2013, s. 124), olarak değerlendirmesi tezat gibi görünse de yazar, durumu bu konuda herkesin bir yorumu olduğu ve belki de herkesin biraz haklı olduğu teziyle açıklar. Sonuç olarak asker yönetime el koymuştur:

Her şey başından beri bir komplo mu, yoksa askeri cuntayla siyasî güçlerin yanlış davranışlarının sonucu muydu? Bu sorunun cevabını asla bilemeyeceksin... Bütün bu söylentiler olayın farklı boyutların anlatıyor. Mesele aynı konuda görüş ayrılıklarından ziyade aynı konunun farklı yönlerinin olması ve belki de en azından bir dereceye kadar doğru olması. Allah Süphânehu Teâlâ'dan başka kimsenin bunu bildiğini de düşünmüyorum. Ben bütün yaşananların bazısının ihmal ve aptallıktan, bazısının intikam ve hırs için bazısının da gafletten kaynaklandı̆̆ını ama hepsinin söndürmek düşüncesiyle daha çok tutuşturan bir yangın olarak görüyorum. Tam olarak gerçeğin ne olduğunu anlamak için kendini yorma evladım. Adı, hileli ya da iptal edilmiş seçim de olsa, darbe, kurtarma operasyonu ya da anlaşma da dense aralarında bir fark yok. Ateşi tutuşturdular ve asker söndürmek için yönetimi ele geçirdi. (Feşîr, 2013, s. 127).

\subsection{Askeri darbe}

Bir ay geçmeden askeri konsey herkesin beklediğinden daha kurnazca yönetimi ele geçirir. Parlamentoyu fesheden asker yeniden başlayan gösteriler üzerine ülkeyi kaostan kurtarmak ve sadece siyasî ve anayasal boşluğu doldurmak için yönetimi üstlendiğini söylese de buna inanamayan halk Tahrir Meydanı'nda toplanmaya devam eder. Bunun üzerine Askeri meclis kamu görevini bıraktığını, anayasa hazırlayarak seçimleri koordine edecek asker-sivil ortak katılımlı yeni bir başkanlık meclisinin oluşturulması için siyasi güçlerle istişareye başladığını duyurur. İhvan dışında bütün siyasi görüşlerin muvafakatini 
alan bu açıklama halk arasında huzur ortamı oluşturmuştur. İhvân'ın gittikçe tırmanışa geçen askeri darbeyi protesto eden gösterileri kimsenin ilgisini çekmez (Feşîr, 2013, s. 129).

\subsection{Geçiş hükümeti}

İki asker, iki sivil ve bir askerî hâkimden oluşan beş üyeli meclisin teşekkül etmesi için çalışmalar başlamıştır. Resmi görüşmelere devrimci hareketi temsilen katılan İzeddîn'le sol görüşü temsilen katılan Mahmûd başlangıçtaki iyimserliklerini kısa sürede yitirerek bunun, sivil vitrin oluşturmak için bir aldatmacadan ibaret olduğunu söylemeye başlarlar. VEFD ve Tecemmu partisi dışında görüşmelerden çekilen siyasî partilere rağmen söz konusu oluşumlarla meclis teşekkül eder. Söz verildiği gibi askeri meclis üyeleri emekliye ayrılarak onların yerine genç subaylar göreve başlamış ve asker, önceliğinin vatanı korumak olduğunu ilan etmiştir. Savunma Bakanlığı görevini anlatıcı-yazarın kayınpederi Albay Kattân üstlenmeye devam eder (Feşîr, 2013, s. 131-132).

Devrimci hareket, askerle İhvan arasına girmek yerine zaman kazanarak gücünü toplamak niyetindedir. Selefîler askerle ittifak yaparken İhvân parmaklıklar arkasında yerini almıştır. İki yıldır kaos ortamından bıkan halk, bildikleri sükûnette işlerini yoluna koyma derdine düşer. Başkanlık Konseyi demokrasiyi politikaları olarak benimseyen yabancı hükümetlere bir vitrin oluşturmuştur. Bu ortamda Asker Menîsî kabine başkanı olarak göreve başlar. Bunun gerçekten bir geçiş hükümeti olacağı inancını taşıyan anlatıcı yazar başkanın basın sekreteri olarak işini sürdürmeye devam eder.

Asker, hakkında soruşturma açılmış bütün siviller hakkındaki kovuşturmayı kaldırıp sokaktan çekilmekle halkın güvenini kazanır. Sahadan çekilmesine rağmen kuvvetlenen otoritesiyle temin ettiği istikrar ortamında halk mutludur. 2013 Mart ayında Kahire'nin kenar mahallerinden birinde ruhsatsız inşa edildiği için yıkım kararı verilen beş bina sakiniyle güvenlik güçleri arasındaki çatışma büyür (Feşîr, 2013, s. 135-136). Birkaç gün sonra bunu şehrin başka yerlerinde maaşları ya da pahalılı̆̆ protesto eden gösteriler izler. Rezervleri tükenen hükümet finans kurumlarının dayattığı ağır şartları fiyatları iki katına çıaracă̆ı gerekçesiyle reddetmiştir. Bu durumda daha fazla banknot basarak açığı kapatmak ister. Bekleyen yatırım ve hizmetlerle gemi her gün biraz daha su almaya başlamıştır. Muhalefetin dikkatini başka yöne çekmek için anayasa teklifini gündeme getiren hükümet, daha önce belli şer'i hükümlerin hazırlanacak anayasada yer alması karşılığ desteğini aldığı Selefîler başta olmak üzere metin üzerinde anlaşamadığı bütün siyasi oluşumların protestosuna maruz kalır. Selefîler "Kâfir Hükümet" sloganıyla silahlanıp sokağa döküldüğünde huzur karşıllğ̣ hürriyetinden vaz geçen halkta sokağa dökülmüştür (Feşîr, 2013, s. 140). Güvenliği artırmaktan başka çare bulamayan Dekûrî hükümetine misilleme olarak Ultraların 2012 yılında gerçekleşen Bur Saîd olaylarında beraat eden 12 subay ve sekiz sivili katlederek resimlerini internette yaymaları üzerine işler çı̆̆ırından çıkar (Feşîr, 2013, s. 134).

Tam da bu sırada İsrail, İran atom tesislerine saldırınca İran buna misilleme olarak Lübnan'daki Hizbullah aracılığıyla Hayfa ve Telabib gibi şehirleri bombalar. Gazze'deki Hamas'in da olaylara karışması İsrail'in Mısır sınırına kadar olan bölgeyi bombalamasıyla sonuçlanır. Selef ve İhvan, hükümeti zor durumda bırakmak amacıyla kamuoyuna Mısır sınırları içindeki Hamas unsurlarının da bombalandığı söylentisini yayar. Mısır hükümeti Hamas'tan bombardımanı kesmesini istemek halinde 'İsrail'in yanında yer almak İsrail'den bunu talep etmekle de savaşta taraf olmakla' suçlanmaktan korkar. İran'ın İsrail'e bizzat karşıllk vermesiyle ABD de savaşa dahil olur. Amerikan gemileri herkesin gözü önünde 
Süveyş kanalından geçtiği gibi Amerika İran'a karşı Mısır hava sahasını kullanır. Mısır hükümeti bunu yalanlarken $\mathrm{ABD}$ hükümeti senatoda tatbikatın iki ülke ittifakıyla yapıldığını açıklar.

\title{
3.5. II. Halk ayaklanması
}

Hükümetin istifası için yapılan gösteriler sonuç vermiştir (Feşîr, 2013, s. 148). Halk ve güvenlik güçleri arsındaki çatışmalarda yüzlerce kişi ölür. Bu karışıklıkta en iyi çözümü bütün ailesini yanına alarak ülkeden kaçmak olarak gören- anlatıcı yazarın kayınpederi Savunma Bakanı Kattân hava alanından arayarak Atina'ya gitmek üzere olduklarını söyler ve kendilerine katılmasını ister. Karısının ihanetine hem şaşırıp hem öfkelenen yazar Mısır'1 terk etmeyi reddeder. Ertesi günü başkanlık binasını yağmalayıp ateşe veren göstericiler onun da ağır şekilde yaralanmasına neden olacaktır (Feşîr, 2013, s. 148-149).

Mahmûd Beşîr, Aynu'ş-Şems hastanesinde bulduğu arkadaşını gizlice gözlerden uzak bir daireye taşır: "Ona göre bu dairede kalmak hastanede kalmaktan daha güvenliydi. Haklıydı da. En azından öfkeli göstericilerin aşina oldukları yüzlere yaptıkları gibi kimse beni aramak, tutuklamak ya da öldürmek için gelmeyecekti." (Feşîr, 2013, s. 153)

Anlatıcı yazar, İfâf, Mahmûd Beşîr, İzzedîn Fehmî ve daire sahibi Abduh'un yardımlarıyla günden güne sağlığına kavuşur. Devrimci hareketle irtibatlı arkadaşları yardımıyla arananlar listesinden adının silinmesinden sonra hayata katılmaya başlamıştır. Grevlerin devam ettiği ülkede hizmetler durmuş, hırsızlık ve yağmalama büyük şirketlerden küçük işletmelere kadar uzanmıştır. Sokaklarda, çevre yolu ve oto yollarda barikat kuran çeteler yolculardan para, saat, yüzük, üzerinde ne varsa almaya başlamıştır. Hiçbir siyasi görüşün hükümet kurmaya yanaşmadığı bu ortamda İzzedîn demokratik sivil güçlerin örgütlenmesi için çalışmaktadır.

\begin{abstract}
Her hâlükârda İzzedîn bıkıp usanmadan suya tohum atmaktan farksız demokratik sivil güçleri örgütlemek için çalışıyor, bir gurup dă̆ılmadan diğgrini topluyordu. Olmayacak bir işle uğraştığın söylesen temel atmak zaman alır karşılığını verirdi. Ona göre yaptı̆̆g şey birlikte çalışma egzersiziydi ve hiç kimsenin ne böyle bir tecrübesi ne de birlikte çalışma alışkanlığı vardı. Bunlar zamanla kazanılacak şeylerdi ve o da bunu yapıyordu. Hoşuna gitmeyen katılmazdı.

Siyasi oluşumlar hükümet kurup anayasa üzerine anlaşmak için çalışmaya devam etti. Selefîlerin İhvân'a karşı askerle anlaşmasından kaynaklanan düşmanlık, devrimcilerin fanatikliği ve sivil demokratlar arasında parçalanma sonucu Ocak ayı yani başkanlık sarayının yakılmasından beş ay sonraya kadar hükümet kurulamadı. (Feşîr, 2013, s. 171).
\end{abstract}

\section{6. İkinci Devrim hükümetleri}

Abbas Fahrî adında çok tanınmayan bir ara bulucu başkanlığında kurulan hükümet, sokaktaki kargaşaya ve ülkenin iktisadi durumuyla baş edecek organlara sahip olmadığı gibi anayasa oluşturacak bir komisyon kurup seçim organize etme gücünden de yoksundur. Arkadaşları siyasi gündemle meşgul olan yazar, Mısır'ın kenar mahallelerinde Ardu'1-Liva semtinde oturan İfâf ve ailesiyle vakit geçirirken daha önce hiç tanımadığı alt tabakanın yaşamına aşina olur. Hastanede böbreği çalınan diğeri de hasar görünce yaptığ ufak tefek işleri de bırakmak zorunda kalan Hasan, beceriksizliğiyle evlerde çalışma fırsatını da kaybeden Mirfet'e göre bunlar hayatın olumsuz yönünde yer almak için yeterli gerekçedir. 
Anlatıc1- yazar İzzedîn'n öğrencilerinden İngiliz ordusunda görev yapan Sara aracılığıyla eşi ve çocuğundan haber alır. Mail üzerinden yaptığı görüşmeler birbirlerini suçlamaktan öteye gitmese de hayata tutunmak için bir sebebi vardır. Bulduğu bir tercüme işinden sonra eskiden olduğu gibi evinde yaşamak istese de ganimet olarak devrimci hareketin eline geçtiğini ve bir aileye tahsis edildiğini görür.

Yazarın hayatıyla birlikte akan siyasi gündem ikici devrim hükümetinin de düşmesinden sonra yeni hükümet kurma çalışmalarıla meşguldür. Devrimci hareketle demokratik sivil güçlerin terk ettiği görüşmeler VEFD İhvan ve Selefîler'in ittifakıyla sonuçlanır. Anlatıcı yazarın görüşmelerden neden çekildiği sorusuna İzzedîn'in cevabı aşağıdaki gibidir:

İslami akım çoğunluk elindeymiş gibi programmı ve görüşlerini dayatmak istiyor. Abbâs Fahrî hükümetinin başarısızlı̆̆ı̆na da onlar neden oldular. Bu yüzden başka bir koalisyon hükümeti kurmanın bir anlamı yok." Yönetimi ele geçirip güçlerini kullanarak oyunun kuralların değiştirmelerinden ve ülkeyi istedikleri gibi yönetmelerinden korkmuyor musun diye sordum. Sirnttp alaycı bir üslupla "Son dokuz aydır meşgul olduğun çok açı" dedi ve ciddiyetini taknarak devam etti: "Hiç kimse her konuda desteklenecek bir çoğunluğa sahip değil, tam tersi şu anda temel sorun parçalanmışllk. Her elli kişinin başlattığı gösteri bir devrime dönüşebilir. Siyasi oluşumlarda da istikrar yok. Her karara karşı çıkan, her fikrin zıddını savunan biri var. Çok az kişi desteklemese de bir kararı kabul ediyor. Toplumdaki herkes tek başına siyasi bir güç olmuş. (Feşîr, 2013, s. 189190).

İkinci devrim hükümeti de kısa bir süre sonra düşer. İslamcıların çağrısı liberal devrimci ve sivil demokratların koalisyonuyla yeni hükümet kurulur. Koalisyonda yer almayan sol görüşlü devrimci hareket gösterilere başlar. Hükümet başkanı Hazım Şaravî tutuklu bulunan devrim düşmanlarının yargılanması için görüşmelerin başladığını ve iktisadî hedefleri duyurur. Üç hafta sonra Bur Saîd özerkliğini ilan edince yeni hükümet de dağılır.

3.7. Millî Birlik hükümeti (Eski yönetim simgelerinin muhakemesi, emniyet teşkilatının yapılandırılması ve ekonomi)

İslamcılar sol eğilimli devrimci hareket ve sivil demokratların ittifakıyla kurulan milli birlik hükümeti ekonominin canlanması için sendikalardan grevlerin altı ay süreyle durdurulması sözünün alınması, güvenliğin yeniden tesisi, yeniden yapılanma ve üç yıldır tutuklu bulunan eski nizam sembollerinin yargılanması konularında anlaşır. Meclisin açılması yeni anayasa ve seçim şartlarının oluşturulması da alınan kararlar arasındadır. Halk yeniden bir nefes alırken anlatıcı yazar da başbakan basın danışmanı olarak göreve başlar (Feşîr, 2013, s. 201).

Göreve sıfırdan başlamam gerektiğini anladım. Eski dosyalarla birlikte bilgi arşivi yangında yok olmuş, ikinci devrimden sonra eski memurlar ya isteyerek ayrılmış ya da görevlerine son verilmişti. Devrim hükümetleri boyunca onlarca akraba ve tanıdık, devrim gazisi ve şehit yakın başkanlık birimi de dahil bütün devlet müesseselerine tayin edilmişti. O zaman bu sorun yaratmayacak makul bir çözüm gibi gözükmüştü. Nasıl olsa bu kadrolar boştu ve yeni bir kaynak aramaya gerek kalmadan maaşlar hazineden karşılanabilirdi. Sonuçta karşımda neredeyse görevini yerine getirebilecek kabiliyetten tamamen yoksun hatta görevinin ne olduğunu bilmeyen bir kadro vardı. Özetle elimizde başkanlık binasından başka bir şey kalmamıştı. (Feşîr, 2013, s. 201). 
Daha önceki Hükümetler de olduğu gibi bu hükümetin önündeki temel sorunlar da aynıdır. Eski yönetim simgelerinin muhakeme edilmeden tutukluluklarının devam etmesi halinde içeride ve dışarıda yaşanan huzursuzluk artmaya devam edecektir. Bir diğer sorun da emniyet teşkilatının yeniden yapılandırılmasıdır. Hükümetlerin aldığı kararlar ayrıntılarda boğulup, idarî, malî ve hukuki engellere takılmaktadır. Devletin güvenlik güçlerine ihtiyacı olduğu bir ortamda köklü değişikliklere cesaret etmek de mümkün değildir. Ekonominin de bütün bunlardan aşağı kalır bir hali yoktur (Feşîr, 2013, s. 210).

Neć Hamadî bölgesinde yaşanan problem ülke sorunlarını daha görünür kılar. Çocuklarının işe alınmasını isteyen bir gurup, alüminyum fabrikasını kuşatarak, çalışmasına engel olmuştur. Hükümetin birkaç işçinin göstermelik olarak işe alınması teklifine fabrika idaresi, olay bir yıl içinde üçüncü kez tekrarlandığı gerekçesiyle karşı çıkınca halk fabrikayı yağmalayarak ateşe verir. İrtibatlı olduğu sendika federasyonlarının desteğine güvenerek gelecek üç yılın da aynı zorlukta geçeceğini açılayan Mahmûd Beşîr sol hareket içindeki rekabet sonucu yalnız kalır. Koalisyon ortakları da siyasi gelecekleri için halkın yanında yer almıştır. Göstericiler yeniden hükümet binasını kuşatır ve Hâzım Şarâvî istifasını açıklar. Herkes yeni kurulacak hükümetin eskisinden daha iyi olmayacağının ve Şarâvî̀nin öfkeli kalabalıkları sakinleştirmek için kurban edildiğinin farkındadır.

Uzun süren arayışlardan sonra İhvân muhâlif konfederasyonlardan bir temsilciye bakanlık verilmesini teklif eder. Sol görüşten Mahmûd Beşîr'in başbakan olması da işçi ve fakirlere son gösterilerde dile getirdikleri taleplere devletin öncelik vereceği güveni telkin edecektir. Siyasi güçlerin hükümet başkanlığından bu kadar kolay feragat etmesi başa çıkılamayacak sorunlarla dolu bir yönetimi devralmaktansa muhalefette kalıp güç toplamak olarak kuşkuyla karşılanır. Ancak güvenliğin tamamen çözüldüğü ve sokak eşkıyalarının ülkeyi teslim aldığı bir dönemde devam eden kaosun üstesinden gelmek daha fazla mümkün olmayacaktır. Amerika'nın Körfezdeki ilerleyişi ve Suriye'deki iç savaş da dışarıda çözülmesi gereken sorunlar arasındadır (Feşîr, 2013, s. 226-227).

Aklyyla çelişiğinde kim duygularna engel olabilir? Çok az kişi ve Mahmûd Beşîr bunlardan biri değgildi. Atılganlı̆̆̆, problem çözme ve tecrübe edinme arzusu çoğunlukla hesaplamalar altüst ederdi. Bu yüzden görevi kabul etti ve bu onun sonunu getirdi. (Feşîr, 2013, s. 229).

Mahmûd Beşîr başkanlığındaki koalisyon hükümeti çalışmalara başlar:

Hükümet programı üzerine yapılan müzakereler çok parlak değildi. Herkes kendi tabanın razı etme çabası içindeydi. En önemlisi de programa mali kaynak bulma sorunuydu. Bütün bu projeleri kim finans edecekti. Mahmûd Beşîr ve ortaklarmın bu soruya verecek bir cevabı yoktu. Bazıları uzun zamandır kötüye giden gelişmelerden endişelenen Arap ülkeleri yardımcı olur derken bazıları ülkenin iflasından korkan ve bölgeye zararı dokunacağını düşünen uluslararası kuruluşlar yardım eder diyordu. Kendi kendime güldüm. İç savaşla uğraşan ya da işgal edilmiş olmasa bile yabancı kontrolünde olan hangi Arap ülkesi yardım eder? Uluslararası kuruluşlar hangi istikrarın bozulmasından korkar? (Feşîr, 2013, s. 236-237).

Tartışma güvenlik teşkilatındaki yapılandırmaya gelince; askeri ve sivil istihbarat sorunu kendi içlerinde çözebilecekleri gerekçesiyle iç işlerini hedef gösterirler. İç işlerinde yapılacak tasfiye için kendilerinden yardım istendiğinde ise aralarındaki hassas ilişki nedeniyle buna yanaşmayıp başkasını kurtarmak için kendilerini kurban etmeyeceklerini 
açıkça ifade ederler (Feşîr, 2013, s. 338). Abdulazîz yeni bir sistem oturtmak için içeriden destek alınamayacağına göre ultralar, selefi ve İhvan polisinden destek almayı teklif eder. Ancak bir araya geldiklerinde birbirlerini yiyecekleri açıktır.

Mahmûd Beşîr iç işlerinde de manevra alanı kalmadığını görünce krizi krizle yönetmeye karar verir. Polis teşkilatının yetkilerini azaltıp maaşlarını yarıya indirecektir.

\begin{abstract}
Bu bana sonuçları güvenli olmayan bir macera geldi. Emniyet çökünce ne olacak diye sordum, haydutların, üçüncü şahısların, ortalığı ateşe verenlerin olduğu günlere mi döneceğiz? Omuz silkti ve "Bana olan onlara da olacak." dedi. "İsterlerse ateşe versinler ortalığı görelim önce kim yanacak" Savaş ruhu onu teslim almıştı, beni en çok endişelendiren de buydu. (Feşîr, 2013, s. 248).
\end{abstract}

İç işlerinde yaşanan bu kriz sırasında Mahmûd Beşî́'in eski kız arkadaşı ve hali hazırda medya patronu Salî Kasapçı'ya fuhuş ağı yönetme suçlaması ülke gündemine oturur. Başlangıçta iç işleri bakanlığının üzerindeki baskıyı azaltmak için hedef yanıltma taktiği olarak değerlendirilen konunun gerçek olduğu anlaşılmıştır. Pek çok siyasinin bulaştığı bu olayla ilgili, konuşma kasetleri, belgeler, banka hesap numaraları ve fuhuş yapan genç kızların itirafları kamuoyuna sunulur. Haydutların başlattığı sokak terörüne devletin müdahale edecek gücü kalmadığı için devrim bekçileri, İhvân ve Selefî polisi karşı koyar. İç işleri ile devlet arasında yaşanan krize daha fazla sessiz kalamayan halk sokağa dökülmüştür, 2015 yılında devlet tamamen çöker (Feşîr, 2013, s. 262).

\title{
3.8. Sivil demokratik gençlik hareketi
}

Abdulazîz'in birkaç yıldır üzerinde çalıştı̆̆ı köy ve mahallelerde sivil demokratik gençlik hareketini teşkilatlandırma girişimi meyve vermeye başlamıştır. Sıra gösteri ve boykot gibi siyasi tavırlardan uzak halkın sorunlarını çözme odaklı bu teşkilatın siyasi arenaya taşınmasına gelmiştir.

Bu yangın ortamında söz konusu hareket sokağı kontrol altına almayı başarır. Mısır Gençlik Birliği adıyla yayınladığı bildiride hükümeti göreve çağırıp, olayların başlamasına kaynaklık eden iç işleri başkanlığına sivil bir siyasinin atanarak sorunun çözülmesini ister ve İzzeddîn'i aday gösterir. Hareketin bir diğer isteği halk komiteleri, İhvan ve Selefi polisi ve devrim bekçilerinin eğitilip silahlandırılarak halk polisine dönüştürülmesi böylelikle yeni polis teşkilatı oluşturulana kadar sokaktaki asayişi sağlamasıdır (Feşîr, 2013, s. 265-266). Uzun uğraşlardan sonra İzzeddîn iç işleri bakanlığının polis teşkilatına tabi hızlı müdahale timleri oluşturması şartıyla görevi kabul eder.

İzzeddîn devletin öncelikli sorunu olan güvenlik teşkilatının oturtulması için mahalli polis adını verdiği bir güvenlik sistemi kuracağını duyurarak halk komiteleri, devrim bekçileri, İhvân ve Selefî polsi bu teşkilata katılmaya çağırır. Halkın kolaylıkla ulaşabileceği bu teşkilat silahsız olup, ihtiyaç halinde Ulusal Muhafız adını alacak hızlı müdahale timinden yardım alacaktır. Sokakta güvenlik sağlandıktan sonra iç işleri bakanlığına bağlı polis teşkilatının iyileştirilmesini hedeflemektedir. Hapishanelerin Adalet Bakanlığı'na bağlanması gibi bir dizi radikal kararı halkın önünde açıklaması onlara uzun zamandan beri ihtiyaç duydukları güveni vermiştir (Feşîr, 2013, s. 284-286). Planının bir parçası olarak hazırladığı polis yasa tasarısını, koalisyon ortakları kabul etmesine rağmen İç işleri bakanlığı üyeleri kabul etmez. Bunun üzerine İzzeddîn bir basın toplantısı düzenleyerek halkın desteğini talep eder.

SEFAD, 2020; (44): 15-36 
Sokaklardan barikatların kaldırılması ve bir düzen getirilmesi sırasında seyyar satıcılarla yaşanan birkaç çatışma dışında her şey yolunda gidiyormuş gibi gözükürken devletin kurumları arasındaki anlaşmazlık bir kez daha sokağa yansır.

\subsection{Provakatif eylemler}

Otobanda yük taşıyan hafif ve ağır vasıta araçlar kendilerine ayrılan sağ şeridi kullanmak yerine hızlı araçlara ayrılan sol şeritten seyrederek sürücülere rahatsızlık vermeye başlamıştır. İç işlerine bağlı trafik polisleri uyarılara rağmen bu davranışa devam eden kamyon sürücülerinin ruhsatlarını ellerinden alır. Sürücülerle polis arasında yaşanan gerginlik sağ şeridi kullanan bir domates kamyonunun trafik polisi tarafından çevrilmesiyle tırmanır. Şoförün aynı davranış nedeniyle ruhsatını kaptırdığını öğrenen polis kamyona el koymaya kalkınca şoför polisi öldürerek ortadan kaybolur. Bir kaç gün sonra kamyoncular yolda provokatif bir tuzağa ateş etmiş, askeri güvenlik güçleriyle yaşanan çatışmada çok fazla can kaybı yaşanmıştır. Kamyoncuların barikatıyla yol tamamen kapatılır. İzzeddîn her ne kadar bunu iç işlerinin kendisine hazırladığı bir tuzak olarak görse de anlatıcı-yazar yıllar sonra dönüp baktığında, yaşananları subayları bertaraf etmek için İzzeddîn'in bir tuzağı olarak görmektedir.

Yolun açılması için güç kullanımını yasaklayan İzzeddîn subayların emniyetini artırmakla birlikte trafik kanununun aynı şekilde uygulanmasını emretmiştir. Onu desteklemek için meydanda toplanan büyük kalabalığın gücünden korkan koalisyon ortakları hükümetten çekilmek ister. İzzeddîn son hamlesini yapmış iç işleri bakanlığındaki komutan ve çalışanlara tutuklama emri çıkartmıştır.

Subayların ihraç edilmesine en büyük desteği ikinci devrim sonrası hapishanede işkenceye maruz kalan İhvân verir. İktidar askeri teşkilatta başlayan kıyımda suçsuz insanlara zulmedildiğinin farkındadır ama devrim karşıtlarını izole etmekten başka çere yoktur. Kadroların boşaltılmasıyla meydana gelen açık, 3. ve 4 . sınıf polis öğrencilerinin sahada uygulama eğitimiyle giderilir (Feşîr, 2013, s. 301). İç işleri bakanı İzzedîn her hükümetin yeterli gücü bulamadığı için ertelediği, tutukluluğu devam eden devrim unsurlarının muhakemesi konusunda da israrlıdır. Uzlaşamaya varamadıkları için Hükümet Başkanı Mahmûd Beşîr'in istifası üzerine göreve talip olan İzzedîn'i başlayan reformların devam etmesi için koalisyon ortakları desteklemek zorunda kalmıştır.

\subsection{Devrim mahkemeleri}

İzzeddîn, 2011 Devrimi kutlamalarında muazzam bir kalabalığın önünde devrim mahkemelerinin kurulacağını ve eğitimden sağlığa, ulaşımdan gösteri düzenleme kanununa kadar yapılacak bir dizi reformu ilan eder (Feşîr, 2013, s. 309).

Emin adımlarla yürüyerek halkın desteğini almaya devam eden İzzeddîn döneminde kurulan devrim mahkemelerinde 7884 kişi idam edilmiştir. Bununla aynı zamanda gerçekleşen mahalli seçimlerde demokratlar sandalye sayısının \%40'ını Selef ve İhvân bir arada \%50'sini, bağımsız adaylar \%10'unu alır. Mahmûd Beşîr'in temsil ettiği sol parti seçimlerde sandalye elde edemez. Kısa bir süre sonra gerçekleşen genel seçim sonuçları da buna yakındır. Seçimlerden sonra başlayan anayasa görüşmelerinde İhvân ve Selefîler'in yeni devlet düzeniyle tamamen ters görüşleri zorluk çıkarmaya başlamıştır:

2016 yazı onunda bir akşam gündemi konuşmak için oturduk. Onu tereddütlü gördüm.

Devrim hedeflerini gerçekleştirmek için yüklendiği bedelin gittikçe arttı̆̆ını söyledi.

Yaşarken de öldükten sonra da vicdanı bu yükü taşımayı kabul etmişti fakat dar 
görüşlülük, Selefiler'in, asker ve memurlarm menfaatlerini düşünmeleri yüzünden bütün bunların boşa gitmesinden korkuyordu. Ona çoğunlukta olduklarını söyledim. Uzun uzadrya baktıktan sonra tam bir ciddiyetle "sorun da bu" diye cevap verdi. Dördüne birlikte karşı gelmek zordu. (Feşîr, 2013, s. 326).

\subsection{Parçala yut politikası}

İzzeddîn hedeflerinin karşısında gördügü dörtlü düşmanı parçalayarak yok etmekte kararlıdır. İkinci devrim sonrası yurt dışına kaçan subayların basına verdiği demeçler, göreve devam eden üst düzey askeri birimleri zora sokacak mahiyettedir. Halkın, adı geçen subayların yargılanması talebine karşı İzzeddîn askerin yanında durarak Savunma Bakanı ve Askeri İstihbarat bakanının değişmesi konusunda onlarla anlaşır. Anlaşma maddelerinden biri de İkinci darbe sonrası yurt dışına kaçan anlatıcı yazarın kayınpederi Albay Kattân'ın yurda dönmesine izin verilmesidir. İzzeddîn'in askerle yaptığı bu anlaşma Selefîler'in üzerine gitmek için elini kuvvetlendirmiştir.

Selefîler'in çoğunlukta bulunduğu Sina yarımadasında yabancı yatırımcıların ilgisini çekecek bir şehir inşa etme niyetiyle başlayan alt yapı çalışmalarına mücahitlerin karşı koymasıyla çıkan çatışmalar gerginliğin başlangıcı olur. İzzeddîn eş zamanlı olarak her hangi bir siyasi gurubun silah taşımasını suç kabul eden yasa tasarısını meclise sunar. Buna karşı çıkan Selefîler sokağa dökülür. Böylece İzzeddîn hem Sina'daki çatışmalar hem silah taşıyan herkesin devrim mahkemelerine sevk edilmesi yoluyla Selefîleri tasfiye eder (Feşîr, 2013, s. 340).

Büronun önüne oturmuş spiral bir tünele girdiğimizi düşünüyordum. Tünelde birbirimizi ezerek kayarken içine düşmeye devam ediyorduk. Bizi boğacak kadar dar olan tünelde kimse çıkış kapısını bilmiyordu. (Feşîr, 2013, s. 343).

2017 Haziran ayında olağanüstü hal kalkar. Eylül ayında anayasa referandumu Ocak ayında yeni seçimler yapılacaktır.

Anayasanın kabulünün ardından İzzeddîn'in açıkladığı kamu görevi kanun projesi yedi yüz cüneyh işsizlik maaşıyla birlikte kamu kuruluşlarında görev yapan memur sayısının ilk yıl yarı yarıya ikinci yıl dörtte bir oranında azaltılmasını hedeflemektedir. İşçi sendikalarıyla sol parti lideri ve devlet başkanı Mahmûd Beşîr buna karşı çıkar. Anlatıcı yazar İzzeddîn ile yaptığı konuşmada sol partinin iktidardan çekilmesi halinde İhvan ve asker karşısında yalnız kalacağını hatırlatması üzerine İzzeddîn, İhvan'a karşı askerle anlaşabileceği cevabını verir.

Sendika ve solcu partilerin gösterileri altında kanun meclisten geçer, Mahmûd Beşîr görevinden istifa etmiştir. İzzeddîn'in daha önce kanunlaştırdığı yasa gereği göstericiler tutuklanarak hapsedilir.

\footnotetext{
Sendikalar eylem yaptıkça polis tutuklamaya devam etti. Oturma eylemi yapanlar polise direnirse "yayılmacı birlikler" olaya müdahale ediyordu. Kasım ayı sonunda devlet dairelerinde sendikalar tarafindan düzenlenen grev ve oturma eylemleri azald ancak sol partiler tarafindan desteklenen ve düzenlenen hareketlilik devam ediyordu. Tam da bu sırada İzzeddîn eski dostu ve müttefikine ve liderliğini yaptığı guruba son darbeyi indirdi.
} (Feşîr, 2013, s. 358).

Polis aralık ayı başında eski ortağı Sâlî Kasapçı'yla birlikte ortağı olduğu şirket aracılığıyla kamu malını gasp ettiği suçlamasıyla Mahmûd Beşîr'i tutuklar. Olayı proteste 
eden tüm solcu guruplar devlete karşı gelme suçundan hapse atılmaya başlamıştır. Bu. tıpkı Selefîler'in tasfiyesine benzeyen ancak savaşmaksızın yapılan tam bir tasfiye hareketidir.

İzzeddîn ve yandaşları bunu zafer olarak görüyordu fakat yanılıyorlardı. Sadece devrim öncesinde olduğu gibi demir yumruk yönetim ve baskı nedeniyle değil, özellikle devlet sektöründe sözleşmeli olarak çalışanlar arasında olmak üzere hayat şartlarındaki kötüleşme nedeniyle memnuniyetsizlik yayılmaya başlamıştı. Bu öfke dalgasına sıranın birkaç ay içinde kendilerine geleceğini bilen geniş bir memur kitlesi de katılmıştı. (Feşîr, 2013, s. 360).

İhvan koalisyondan çekilir ve İzzeddîn olağan üstü hal ilan eder. Mahmûd Beşîr başta olmak üzere devrim düşmanı suçlamasıyla yedi kişinin idamına karar verilir.

Sana itiraf ederim ki arkadaşımın darağacına gideceği şu âna kadar idam edilen diğerleri birer rakamdan ibaretti fakat o bir rakam değildi. O anda, İzeddîn'in kurduğu güzel vatan hayalini gerçekleştirmek için kötülerle savaşan yumuşak huylu bir arkadaş değil bir katil olduğunu hissettim. (Feşîr, 2013, s. 368).

İdamın ardından Bütün Mısır'a hâkim olan sessizlik bir hafta sonra bozulur. Bu kez polis göstericilere müdahale etmekten vaz geçmiştir. Başkanlık meclisi, devletin birliğini tehdit ettiği gerekçesiyle İzzeddîn Fikrî’yi devrim mahkemesine sevk eder ve İzzeddîn idam edilir.

Bürosunda çalışanlar ve sınırlı sayıda bürokratlar dışında, yandaşlarından şu anda siyasi arenada boy gösteren kimse buna itiraz etmedi. İzeddîn'den ve demir yumruk yönetiminden yorulup onu düşmanlarna teslim mi etmişlerdi? Yoksa daha sonra ondan kurtulup geçmişin günahın yüklenmeden yönetimi ele geçirmek üzere bu zor görevi yerine getirmesi için onu kullanmışlar mıydı? Ya da Ihvan ve askerin birlikte yaptı̆̆g baskıdan buna mecbur kalmışlar ve siyasi tavırlarına mâl olabilecek bir çatışmadan kurtulmaya mı karar vermişlerdi? (Feşîr, 2013, s. 370).

Beki de İhvan hakl. Bütün kararları insana brrakmak doğru değil. Kim demiş insanlar arasında eşitlik mümkün diye? Kim Demiş adaletin mümkün olduğunu? Toplumsal ıslahın mümkün olduğunu kim söylemiş? Ĕ̆er insan anarşiye, zulme, ayrımcilğa ya da rezilliğe razıysa neden birisi çıkı da kendilerine rağmen onları değiş̧tirmeye çalışıyor? (Feşî, 2013, s. 384).

\subsection{2. İhvan hükümeti}

Geçiş hükümetinin yaptığı seçimlerde İhvan sandalyelerin yarısından fazlasını alır ve Saîd Beyûmî 2011 yılından beri ilk kez seçilmiş bir başkan olarak göreve başlar. Hükümetin ilk altı ayda aldığı en önemli karar IMF ve uluslararası bankalardan kredi almayı durdurmak olur. Hükümet bunun yerine Haliç ülkelerinden destek almayı hedeflemiş̧ir. Toplumsal yardımlaşmayı yaygınlaştııır, gönüllü sağlık vb. hizmetlerin fakir ailelere ulaşmasını sağlar.

Beyûmî'nin aldığı bir diğer önemli karar da Filistin'le Mısır arasındaki Gazze koridorunun açılması olur.1962 yılından beri kapalı olan bu koridorun açılması hükümetin Orta doğudaki itibarını artırmıştır. Toplumsal hizmet çemberinin genişlemesi ve İzzeddîn döneminde atılan işçilerin geri alınması devletin yükünü artırsa da hükümet zaten çökmüş olan ekonominin desteğe ihtiyacı varken daha fazla yüklenmenin ne zararı olur düşüncesindedir. Beyûmînin Iranla yaptığı anlaşmalar ve koridorun açılması Amerika'nın 
yakından takip ettiği konular arsında yer almaktadır (Feşîr, 2013, s. 388-389). Hükümet Çin'le yakınlaşmak suretiyle Amerika'ya karşı güçlü bir devleti kendine kalkan yapma politikası güder.

Ancak İran'ın bir yere kadar olan cömertliği gibi Amerika'nın da sabrı taşmak üzeredir. Sina yolundan Gazze'ye giden yük kamyonları içine gizlenmiş, İsrail'de belirlenen hedefleri bombalamada kullanılacak küçük yer füzeleri İsrail tarafından fark edilince Mısır hükümeti önce yalanlayıp sonra bilgimiz dışında gerçekleşmiştir açıklamasıyla olayı geçiştirmeye çalışır.

Şubat ayından beri devam eden süreç sonucu Eylül ayında Tel Aviv'deki Ben Gurion hava limanının bombalanması şaşırtıcı olmaz. Bazıları silah kaçakçılığı ile başlayan bu sürecin İsrail hükümetinin Mısırı savaşa çekmek için yaptığı bir düzen olduğu düşüncesindedir. Zira İsrail Filistin'in bunu yapacak güce sahip olmadığını ve Mısır'dan ülkeye giren İranlı dostlarının yardımıyla bu eylemi gerçekleştirdiğini açılayarak Filistin topraklarındaki İran ve Mısırlıların İsrail'e teslim edilmesini ister. Öte yandan Misır halkı ve genel olarak Arap kamuoyu olayı büyük bir sevinçle karşılamış halk Beyûmî ve hükümetini kutlayan gösteriler yapmaya başlamıştır.

İsrail yeni açılan koridorun kapatılarak gözetim altında tutabildiği eski koridorun kullanılmasını ve böyle bir eylemin bir kez daha gerçekleşmemesi için ortak devriyelerin oluşturulmasını ister. Amerikan filosu Sina yarımadasında, Kızıldeniz ve Akdeniz'de konuşlanarak şüpheli gördügü gemileri arayacaktır. Bu durum karşısında Mısır Hükümet Meclisi Güney kanal girişinde demir atan Amerikan gemisini bombalayıp saklanarak sorumluluğunu bir cihat örgütünün üslenmesini planlamıştır. Gemiden yapılan karşı atış neticesinde anlatıcı yazarın kız kardeşi eşi ve çocuklarının da aralarında bulunduğu pek çok mısırlı hayatını kaybeder (Feşîr, 2013, s. 400-407). Kısa bir süre sonra İsrail Sina'ya doğru ilerleyerek Şerm Şeyh ve Sina'nın doğusunu alır. Hükümet başkanı Beyûmî taarruz kararı vermiştir, ancak uygulayacak fırsat bulamadan Asker Mısır'ı kaosa sürüklediği gerekçesiyle yönetime bir kez daha el koyar (Feşîr, 2013, s. 414).

\subsection{Askeri darbe}

Askeri darbeye karşı çıkan halkın ve siyasi partilerin direnişine asker; kurtuluş meclisi adı altında bir geçiş hükümeti olarak görev yapacağı siyasi partilerle istişare ederek ve sivil yapılanmaya dokunmamak suretiyle çalışacağı açıklamasını yapar (Feşîr, 2013, s. 416).

Sorularla yüzleşmekten kaçamam. Bütün bunlar olurken ben neredeydim? Koltukların arasında olan bitene şahit olan bir çevirmen miydim sadece? Nur'un yılardır iddia ettiğ $i$ gibi yapabileceğim bir şey yoktu ve ruhumu korumak için istifa mı etmeliydim? Yoksa o yanılıyor mu, çekilmek yerine yapmam gereken şeyler var mıydı? Ilk devrimden önce İzzeddîn'in benden istediğ gibi başkanın kulă̆ına gerçekleri fısıldamalı mıydım? Başkan İzeddîn insanları dară̆acına gönderirken sessizce ya da haykırarak ona karşı mı çıkmalıydım? Sivillerin ortasındaki bir savaş gemisine saldıran aptallara karşı çıkmalı mıydım? Bunlardan hiç değilse birini yapabilir miydim? Yoksa ben sadece bir şahit, çevirmen ve oturum kâtibinden mi ibarettim?

Fakat ne fark eder ki? Müdahale etmemle etmemem arasinda ne fark var? Bütün plan ve projesine, bütün ihtiyatına, araştırmasına, zekâ ve savunmasına rağmen bir kan dökücüye dönüşmedi mi? Bütün deliliği atılganlığı duyguları ve samimiyetiyle çabalamasına rağmen Mahmûd'un sonu dară̆acının sahibi gibi idam ipi olmadı mı? Benim gibi duygu 
ve düşüncelerini ikna edici bir kalıba dökemeyen sessiz sakin bir çevirmen ne yapabilir ki?

(Feşîr, 2013, s. 419).

Gelip geçen bunca hükümetler dökülen bunca kan Mısırı́n özgürlüğü için değil bazen siyasi liderlerin milliyetçi arzularla başlayıp bilenen hırsları, bazen tamamen koltuk sevdaları, kendi ideolojilerini gerçekleştirmek için halkı kurban etmelerinden ibarettir. Albay Kattân yönetimdeki önceliklerini aşağıdaki cümlelerle ifade eder.

Basın sekreteri olarak görevine devam eden anlatıcı yazara Kattân öncelikli sorunun ne olduğunu sormuş, verdiği İsrail işgali cevabı aşağıdaki gibi karşılık bulmuştur:

Gözlerinden yaş gelene kadar güldü. Gözyaşların silerken bana İsrail Sina'yı yirmi yıldan daha fazla işgal etse ya da yirmi yıllı̆̆ına Sina'yı özgürlüğ̈̈ne kavuştursak ne fark eder? diye sordu. İrkilmiş suskunluğum ortasında bana ilk ve en önemli önceliğimiz istikrar, devletin prestiji ve hükümetin otoritesi, diğgerleri bekleyebilir, dedi. İsrail düşmanlığına engel olmadan bir şey yapamayız deyince, önemli olan yapıyormuş gibi görünmek karşılı̆̆ını verdi.

Kattân ve arkadaşları siyasi partilerle uzlaşı halinde gösteri ve mitingleri yasaklamayıp onları teneffüs kabul eden bir felsefeyle hareket ederler. Sina Ulusal Kurtuluş Komitesi 'ni kuran hükümet her toplantıda çözüm getirmeyeceğini bildiği kararlar alır. Ancak Kattân'ın devlet idare sanatı umduğu gibi gitmez. Sina'dan çımak istemeyen İsrail ve İhvan'la demokrat gençlerin "Birliktelik" adı altında yaptığı çalışmalar ülke genelinde yaygınlaşmaya başlamıştır.

Kattân işin ciddiyetinin farkına vardığında Çin'den satın alacağı atom bombasını İsrail'e atmayı son çare olarak görür. Gizli bir görev olarak kendisine ve Menîsî́ye teklif edilen görevi çılgınlık olarak gören anlatıcı yazar, reddetmesi halinde başkasına verileceği endişesiyle yolda sabote etmek için Amerikan istihbaratıyla yazışır. Dönüş yolculuğunda yazdığı bütün yaşam hikâyesini anlatan bu mektupta ilk defa cesaret edip Mısır için bir şey yapmak istediğini söyleyerek adeta özgürlük uğruna verilen bütün kurbanlardan özür dilemektedir.

\section{SONUÇ}

Hem yazarın içinde doğduğu hem de yansıttığı alan olarak toplum edebiyat ilişkisi bir edebi eseri anlamak için ait olduğu toplumun tarihi ve coğrafi şartlarını dikkate almanın yanında yazarın hayat hikâyesiyle de ilişkilendirmeyi zorunlu kılmaktadır. Bu perspektiften hareketle, İzzeddîn Feşîr'in ihtisas alanı olan siyaset bilgisini kullanarak, Mısır Arap Baharının paydaşlarını oluşturan siyasi partiler iktidar ve halk arasındaki dengelerle kurguladığı Bâbu'l-Hurûc adlı romanı, tarihi gündem çerçevesinde değerlendirmek doğru olacaktır.

Ortadoğu ülkelerinin demokrasi açmazı olarak klişeleşen kalıbı Batı merkezli şarkiyat araştırmalarına hapsederek her ülkeyi yapısal ve kuramsal şartları etrafında değerlendiren yeni çalışmaların söz konusu ülkelerde iç görü geliştirmesi ve kendi şartlarına odaklanarak çözüm üretmesi ümit edilir. Söz konusu romanda yazar, 2011 yılında Tahrir Meydanı'nda daha fazla demokrasi talebiyle başlayan eylemlerin otoriter rejimlerin sürekliliğinde kırılma noktası oluşturamamasına odaklanmış, siyasi liderlerin politik tavırlarında gözlemlediği hataları kurguladığı olaylarla sergilemiştir. Bu tavırları aşağıdaki şekilde ifade etmek mümkündür: 
- Seçimle gelen İhvân iktidarına el koyan askere sol oluşum güç kazanmak, Selefîler de askerle ittifak yaparak sandalye kazanmak için ses çıarmamış, böylece İhvân parmaklıklar ardına gönderilmiştir.

- Ülkenin temel sorunu olan ekonomi her iktidar döneminde göz ardı edilmiş, muhalefetin ve halkın dikkatini başka yöne çekmek için yapılan düzenlemeler gizli ittifaklar arasındaki anlaşmazlıklara kurban gitmiştir.

- Müslüman halkın zayıf noktası olan Filistin sorunu iktidar tarafından güven tazelemek için kullanılmış, Amerika'yla yapılan iş birliği halktan gizlenmiştir.

- Misır başta olmak üzere demokrasi sorunu yaşayan ülkelerde askerî darbeler keskin bir kılıç olarak daima iktidarın tepesinde durmaya devam etmiştir.

- Demokratik Sivil Örgütlenme adıyla başlayan iyi niyetli oluşumlar bile demokratik yoldan ilerlemek yerine provokatif eylemlerle hareket ederek binlerce insanın ölümüne neden olmuştur.

- İktidarı paylaşan sivil ve askeri idareciler kendi menfaatini ülke menfaatinden üstün tutarak gerekli reformların yapılmasına direnç göstermiş çözülemeyen sorunlar yüzünden ilerleme kaydetmek mümkün olmamıştır.

- Özellikle darbe döneminde yetişmiş eleman yokluğunda şehit ve gazi yakınlarının kamuda görevlendirilmesi daha sonra liyakatle ilgili sorun oluşturmuştur.

-Koalisyon hükümetlerinde herkesin kendi tabanını razı etme ve bir sonraki seçime yatırım arzusu ileriye yönelik köklü temellerin atılmasına engel teşkil etmiştir.

Yazar politik manevraları bir nakış gibi işlediği romanda kurgusal aktör ve hikayelerle değişmeyen gerçeklere işaret ederken, demokrasi sorununun kaynağını halktan ziyade iktidarların tutumunda aramak gerektiğine ve demokrasinin kişisel menfaatlerden feragat etmekle mümkün olacağına işaret etmektedir.

\section{SUMMARY}

İzzeddîn Şükrî Feşîr's novel Babu'l-Hurûc (the Gate of Exit), which was released in 2012, is a collection of letters consisting of 473 pages 15 chapters that were written by young Ali Şükrî to his son Yahya during his duty as a translator at the presidential palace throughout Hüsnü Mübarek's period. The authoor's book written in Fasih Arabic is an autobiography of Ali Şükrî. Starting to work as a translator in the presidential palace in 1991, Ali Şükri later joins meetings with heads of states as the private translator of the president, and narrates the political stream beginning with resistance movement in 2001 and continues until 2020 blending it with his own life story. . The success of the novel written in 2012 lies in the fact that the author's foresight on the country's politics came true to a great extent.

While the literature makes its bond to society stronger with both the society the author was born into and reflected on, generally literary works especially novel will be hard to understand without the political and social conditions of the society it belongs to. . Sometimes you need to evaluate a work thoroughly by not only trying to understand it on a sociological, Marxist or historical level externally but also by extracting the parts finding their way from the author's life to the novel.

It will be wise to comment on İzzeddîn Şükrî Feşîr's novel Bâbu'ul Hurûc -a fiction of possible political and economical events that might take place in the social and political

SEFAD, 2020; (44): 15-36 
domain until 2020 with reference to the country's history and existing conditions,-that was written one year after Arab Spring occurred in 2011, in an interdisciplinary way. The author built a scenario using his area of expertise -politics- by designing a perfect scheme including the actors coming from the political history of the country, the society's expectations, the reflections of international politics on national politics.

It will not be possible to write just one single scenario on the democratic deficit in the Middle East countries. Since the equation stemming from structural, theoretical and sometimes cultural conditions is different in every country, the struggle for democracy in these countries unfolds differently too. When it comes to Egypt among all these countries, the regime's relation with the partners during the coalition period, its relation with the opposition parties when it came to power alone and the share the army got from instate structures form the sides of this equation. Managing the opposing manners of nongovernmental organizations (NGOS) must be included too. When the opposition parties' active politics are interrupted by oppression and arrests, the expression of "Radical İslam" appointed to Islamic organisations makes grounds for halting their activities. One should not forget to add the external Powers' support for the regime to this combination.

The obstacle in front of Egypt's transition to democracy is the existence of military forces on top of the society and behind the government, rather than structural approach explaining the continuity of authoritarian regimes in the Middle East countries. The reason why democratic movement was more successful in Tunusia rather than Egypt is that the army has less power in the government compared to Egypt. The military's active role in the government is based on the coup in 1952. Switching to liberal economy with Ifftitah programme after Nasir, the military gained commerical privileges during Sedat's period. Its increasing commercial power during Mübarek's time, and simultaneously active Palestine problem which legitimised Arab regimes have enabled it to possess corporate autonomy against political mechanisms despite being one of them.

After studying Political Sciences in Cairo, and doing doctorate on the same field in Canada, İzeddîn Şükrî creates effective characters in the country's politics for his novel. In order to give meaning to the political equation, which he designed after the revolution, with those characters you need to add political opportunist approach generally for Middle East, and specifically for the Egyptian government.

In Egypt, the opportunist approach to explain a wide range of political subdivions with different views getting together in coalition governments will raise awareness to these political combinations in the novel. The main argument of this analysis is that the government makes use of the space it has created for the opposition. In time, this interaction may either give a new meaning to ideologies or may be limited to using the afore mentioned opportunities. We need to interpret İhvan's pragmatic relations with the coalition governments or the opposing party within that context. It will be useful to follow the ruling strategies and the stream maintained with the political maneuvrs of the cabinets established after Arab Spring in the author's novel in the light of that information. 
Makale Bilgileri

Etik Kurul Kararı:

Katılımo Rızası:

Mali Destek:

Çıkar Çatışması:

Telif Hakları:

Article Information

Ethics Committee Approval:

Informed Consent:

Financial Support:

Conflict of Interest:

Copyrights:
Etik Kurul Kararından muaftır.

Katılımcı Yoktur

Çalışma için herhangi bir kurum ve projeden mali destek alınmamıştır.

Çalışmada kişiler ve kurumlar arası çıkar çatışması bulunmamaktadır.

Telif hakkına sebep olacak bir materyal kullanılmamıştır.

Exempt from the Ethics Committee Decision.

No participants

No financial support from any institution or project.

No conflict of interest.

No material subject to copyright is included. 


\section{KAYNAKÇA}

Bekaroğlu, E. (2017). Otoriter bir rejimde muhalif olmak: Müslüman Kardeşler, siyasal fırsat alanları ve siyasal kuşaklar. N. Doğan (Ed.), Ortadoğu'da Çatışma ve İdeolojiler içinde (s. 111-163). İstanbul: İnkılap Kitabevi.

Bekaroğlu, E. ve Kurt, V. (2015). Misır'da otoriter rejimin sürekliliği ve ordu: "Arap Baharı" ve sonrası sürecin analizi. Türkiye Ortadoğu Çalışmaları Dergisi, 2(2), 1-36. Erişim adresi: https://dergipark.org.tr/tr/download/article-file/159447 Erişim tarihi: 03.07.2020.

Demirtaş, E. (2014). Ortadoğu'da Devlet ve İktidar. İstanbul: Metis Yayıncılık.

Esposito, L. ve Voll, J. (2012). İslamiyet ve Demokrasi. İstanbul: Köprü Kitap.

Feşîr, İ. (2013). Bâbu'l-Hurûc. Kahire: Dâru'ş-Şurûk. 